\title{
The impact of the Government Program for Social Participation of Senior Citizens (ASOS) on social activation of the elderly in Poland: Findings from a qualitative study
}

\begin{abstract}
The main aim of this paper is to present the impact which the Government Program for Social Participation of Senior Citizens (in Polish: Rządowy Program na rzecz Aktywności Społecznej Osób Starszych; ASOS) for the years 2014-2020 had on the social activation of the elderly in Poland, based on a case study of one project. The first part of the article presents a justification for research concerning the activation of the elderly in Poland. Next, the paper discusses the main objective of ASOS, as well as its significance as the first national-level public intervention for social activation of the elderly in Poland. Then, the effects of ASOS on the social activation of the elderly are analyzed. The analysis is based on a qualitative approach to impact evaluation of the Active Regardless of Age project, which was co-financed by ASOS. Finally, the authors identify a list of various types of outcomes achieved by the project which apply to social activation of the elderly. Moreover, the issue of generalizing the project findings for the entire ASOS is discussed. Finally, the paper
\end{abstract}

1 University of Wrocław, Poland, e-mail: malgorzata.michalewska-pawlak@uwr.edu.pl, https://orcid. org/0000-0003-1371-1242

2 University of Wrocław, Poland, e-mail: monika.klimowicz@uwr.edu.pl, https://orcid.org/00000002-0605-7839 
presents research results of the Innovative Social Investment: Strengthening Communities in Europe (InnoSI) project funded under the Horizon 2020 Program.

Keywords: active aging, senior policy, impact evaluation

JEL Classification Codes: H43, H53, I38

\section{Wpływ Rządowego Programu na Rzecz Aktywizacji Społecznej Osób Starszych (ASOS) na społeczną aktywizację osób starszych w Polsce. Wnioski z badań jakościowych}

\section{Streszczenie}

Celem głównym artykułu jest analiza wpływu Rządowego Programu na Rzecz Aktywizacji Społecznej Osób Starszych (ASOS) realizowanego w latach 2012-2020 na społeczną aktywizację osób starszych w Polsce, na wybranym przykładzie konkretnego projektu. W pierwszej części artykułu zaprezentowano uzasadnienie dla prowadzenia badań naukowych nad społeczną aktywnością seniorów w Polsce. Następnie przedstawiony został cel główny Programu ASOS oraz jego znaczenie jako pierwszej publicznej interwencji prowadzonej z poziomu centralnego w Polsce na rzecz wzrostu społecznej aktywności seniorów, na podstawie analizy wybranego studium przypadku: projektu Aktywni bez względu na wiek, współfinansowanego przez Program ASOS. Dzięki implementacji jakościowego podejścia badawczego do ewaluacji dokonano identyfikacji efektów interwencji Programu ASOS, które dotyczą aktywizacji społecznej badanych seniorów. W dalszej części omówiona została kwestia generalizacji wyników badań jakościowych konkretnego projektu dla całościowej ewaluacji Programu ASOS. Tekst opracowania powstał na podstawie wyników badań uzyskanych w ramach projektu Innovative Social Investment Strenghtening Communities in Europe (InnoSI), współfinansowanego w ramach programu badawczego Horyzont 2020.

Słowa kluczowe: aktywne starzenie się, polityka senioralna, ewaluacja wpływu

Kody klasyfikacji JEL: H43, H53, I38

\section{Introduction: the context of the study}

The growing number of older adults in the age structure of the Polish population has been clearly visible in the last decade. In 2014, 15.3\% of the Polish population was aged 65 and above (GUS, 2016: 3). Similar to other European countries, Poland has witnessed a rapid rise in the number of the elderly. According to the Statistics Poland 
(in Polish: Główny Urząd Statystyczny, GUS) data, in 2035, the estimated percentage of those aged 65 and above in the age structure of the Polish population will be 23.2\% (GUS, 2009: 182). Furthermore, this increase is associated with the phenomenon of "double demographic aging," whereby there is a simultaneous growth of the population aged 65 and above and the population aged 80 and above (Rokicki, 2016: 189). Should the predictions be accurate, this situation poses a serious economic, social, and political challenge related to the directions of public income redistribution and public expenditure. Consequently, the process of population aging, which has a long-term nature, and its future consequences for the labor market, family life, long-term care services, healthcare, and retirement systems have been the subject of many studies (Błędowski, 2017; Kiełczewska, Lewandowski, 2017; Leszko et al., 2015).

The Government Program for Social Participation of Senior Citizens (in Polish: Rządowy Program na rzecz Aktywności Społecznej Osób Starszych; ASOS) is one of the main instruments of an active aging policy programmed and financed in Poland after 1989 at the national level. It was developed as a result of two processes: the accession of Poland to the European Union (EU), where support for active aging of the elderly is a part of social investment policy (Wiktorska-Święcka et al., 2017) and the ongoing process of population aging in Poland. ASOS has been developed by the Ministry of Labor and Social Policy (in Polish: Ministerstwo Pracy i Polityki Społecznej; MPiPS) since 2012, as a response to the challenges which have emerged as a result of demographic and social changes in Poland. The definition of active aging, which is the most widely used, has been proposed by the World Health Organization (WHO): "the process of optimizing opportunities for health, participation, and security in order to enhance the quality of life as people age" (WHO, 2002: 12). It means that active aging is not limited only to the physical dimension, but it refers to the social, cultural, and professional participation of senior citizens. The active aging policy has been developed in the European Union since the 1990s, and the European Commission approved some recommendations for this policy implementation: increasing the employment of elderly people, reversion of early retirement trends, research development in the area of old-age care and health, combating discrimination and social exclusion of senior citizens (EC, 1999). Although some researchers claim that the EU active aging policy is strictly oriented towards economic productivity (Walker, 2009; Boudiny, 2013), it offers the model of the active role of the elderly in society.

The Polish accession to the EU can be described as a milestone in terms of shaping the active aging policy since the European Social Fund (ESF) provided financing for the first projects aimed at meeting the professional and social needs of older adulds. However, what sets ASOS apart from other active aging policy instruments is its objectives, which focus on the social activation of the elderly in order to improve 
their standard and quality of life. ASOS has a comprehensive character due to the fact that its implementation is oriented towards the improvement in the quality of life of older adults in varied aspects.

Impact evaluation is a methodological tool that enables examination of the influence of ASOS on social activation of the elderly, who are its main beneficiaries. The analysis is based on a case study of the Active Regardless of Age project, which was supported by ASOS in 2015. The research presented in this article is a quality study; sources of information and research methods were used to evaluate the outcomes of a single project $(n=1)$, which was implemented in the framework of the ASOS intervention. It is worth mentioning that although this analysis is not representative of the whole ASOS, the impact evaluation of one project is indicative of various types of general outcomes in the area of social activation of senior citizens; some of the outcomes were not identified and planned at the planning stage of ASOS. Moreover, the impact evaluation of the project allowed examining the conditions for success or failure of the intervention and identify its costs and benefits (Gertler et al., 2011). Nonetheless, in order to reach general conclusions about the intervention, the results of the impact evaluation of the Active Regardless of Age project should be compared with other studies of projects provided for by ASOS (Klimowicz, MichalewskaPawlak, 2018: 102).

\section{Social activation as the main objective of ASOS}

The main rationale for the development and implementation of ASOS was that the EU designated 2012 as the European Year for Active Ageing and Solidarity between Generations (European Parliament and European Council, 2011). ASOS was the first public policy program in Poland whose objective was to promote the well-being and extend the working life of older adults through engagement in social activities, such as volunteering and taking advantage of learning opportunities. ASOS was a breakthrough in the area of active aging policy because it focused on meeting the wider social needs of the elderly (Kubiak, 2015: 337-353).

There were two editions of ASOS, 2012-2013 and 2014-2020. The main goals of both editions were the improvement of the quality and standards of living of the elderly and ensuring dignified aging through engagement in social activities. In both editions of ASOS, the same four specific objectives were defined; furthermore, specific performance indicators for measuring the level of goal achievement were assigned.

The indicators for ASOS presented in Table 1 partially overlapped in both editions; however, some were slightly altered. In the second edition, there was a greater 
emphasis on the development of volunteering, which was reflected in the newly introduced indicators. Regardless of the edition of ASOS, its evaluation is based on quantitative indicators.

Table 1. Objectives of 2012-2013 and 2014-2020 ASOS

\begin{tabular}{|c|c|c|}
\hline Objectives 2012-2013 and 2014-2020 & Indicator measurement & Source of verification \\
\hline $\begin{array}{l}\text { Main objective } \\
\text { Improvement of the quality and standard } \\
\text { of life of older people for the dignified } \\
\text { aging through social activity. }\end{array}$ & $\begin{array}{l}\text { - Respondents at the age of } \\
60 \text { working in civil society } \\
\text { organizations } \\
\text { - Voluntary work in organizations } \\
\text { and outside organizations at the } \\
\text { age of } 60\end{array}$ & $\begin{array}{l}\text { - Centre for Public Opinion } \\
\text { Research (in Polish: Centrum } \\
\text { Badania Opinii Społecznej; CBOS) } \\
\text { - Statistics Poland (in Polish: } \\
\text { Główny Urząd Statystyczny; GUS) }\end{array}$ \\
\hline $\begin{array}{l}\text { Specific objective no. } 1 \\
\text { Increasing diversity and improving the } \\
\text { quality of learning opportunities for older } \\
\text { people. }\end{array}$ & $\begin{array}{l}\text { - The number of new participants } \\
\text { - The number of newly created } \\
\text { activities } \\
\text { - The average monthly number of } \\
\text { hours of newly created classes } \\
\text { for elderly people } \\
\text { - The number of volunteers } \\
\text { participating in projects }\end{array}$ & $\begin{aligned} \text { - } & \text { Reports on the Program } \\
& \text { implementation } \\
\text { - } & \text { Reports on the Program } \\
& \text { implementation } \\
\text { - } & \text { Reports on the Program } \\
& \text { implementation } \\
\text { - } & \text { Reports on the Program } \\
& \text { implementation }\end{aligned}$ \\
\hline $\begin{array}{l}\text { Specific objective no. } 2 \\
\text { Creating the conditions for integration } \\
\text { between and within the elderly using the } \\
\text { existing social infrastructure. }\end{array}$ & $\begin{array}{l}\text { - The percentage of people } 60+ \\
\text { who regularly use a computer } \\
\text { - The number of beneficiaries } \\
\text { participating in the newly created } \\
\text { project } \\
\text { - The number of volunteers } \\
\text { participating in projects }\end{array}$ & $\begin{array}{l}\text { - The information society in Poland: } \\
\text { The results of a statistical survey } \\
\text { - Reports on the Program } \\
\text { implementation } \\
\text { - Reports on the Program } \\
\text { implementation }\end{array}$ \\
\hline $\begin{array}{l}\text { Specific objective no. } 3 \\
\text { Development of various forms of social } \\
\text { activities, including the promotion of } \\
\text { voluntary work, participation in decision- } \\
\text { making processes, including the elderly } \\
\text { involvement in shaping public policy. }\end{array}$ & $\begin{array}{l}\text { - The number of projects } \\
\text { submitted in the area of public life } \\
\text { participation of elderly people } \\
\text { - The number of newly created } \\
\text { network/care centers of } \\
\text { assistance and information } \\
\text { - The number of beneficiaries } \\
\text { participating in the newly created } \\
\text { project } \\
\text { - The number of volunteers } \\
\text { participating in projects }\end{array}$ & $\begin{array}{l}\text { - Reports on the Program } \\
\text { implementation } \\
\text { - } \text { Reports on the Program } \\
\text { implementation } \\
\text { - } \text { Reports on the Program } \\
\text { implementation } \\
\text { - Reports on the Program } \\
\text { implementation }\end{array}$ \\
\hline $\begin{array}{l}\text { Specific objective no. } 4 \\
\text { Increasing the availability, improving } \\
\text { the quality of social services, and } \\
\text { support activities for self-help and self- } \\
\text { organization. }\end{array}$ & $\begin{array}{l}\text { - The number of beneficiaries of the } \\
\text { new social services } \\
\text { - The number of beneficiaries } \\
\text { of new forms of self-help } \\
\text { - The number of volunteers } \\
\text { participating in projects }\end{array}$ & $\begin{array}{l}\text { - Reports on the Program } \\
\text { implementation } \\
\text { - Reports on the Program } \\
\text { implementation } \\
\text { - Reports on the Program } \\
\text { implementation }\end{array}$ \\
\hline
\end{tabular}

Source: own elaboration based on MPiPS (2012: 19-20) and MPiPS (2014a: 10-11).

The objectives of ASOS are based on four priorities: the education of the elderly; promotion of social activation, intragenerational and intergenerational integration participation of the elderly in social activities; and social services for the elderly. 
With a total program budget of PLN 280 million, non-governmental organizations, sports clubs, and associations of local governments were encouraged to keep older adults active and healthy. Since the commencement of ASOS, the Ministry of Family, Labor, and Social Policy (in Polish: Ministerstwo Rodziny, Pracy i Polityki Społecznej; MRPiPS) has published six evaluation reports on ASOS implementation, respectively in 2013, 2014, 2015, 2016, 2017, 2018 (MPiPS, 2014b, 2015; MRPiPS, 2016; MRPiPS, 2017; MRPiPS, 2018; MRPIPS, 2019). The reports include figures by the number of bids in relation to co-financed projects in 16 Polish regions; types of organizations applying for funds; the number of applications submitted under individual priorities of the program; the number of offers made collectively by at least two non-governmental organizations; and financial allocation. Both editions of ASOS were evaluated on the basis of statistical data and quantitative research. The used measurements were directly connected with the Active Aging Index (AAI) (Klimowicz, Michalewska-Pawlak, 2019: 11). The evaluation of ASOS implementation between 2013 and 2017 was also made by the Supreme Audit Office (SAO; in Polish: Najwyższa Izba Kontroli; NIK). The SAO examined the effectiveness of management and the level of achieving the objectives of ASOS. The final evaluation report also includes an examination of opinions about ASOS given by 847 seniors who participated in the program between 2016 and 2017. This evaluation was of a quantitative nature and concerned the assessment of the intervention (NIK, 2019:23).

Nevertheless, the criteria adopted in quantitative evaluations of ASOS failed to define the factors that have a positive or a negative impact on the achievement of the objectives of the program. It appears that qualitative research is necessary to diagnose the context, conditions, and mechanisms that determine the success or failure of ASOS implementation and that pose a threat to the achievement of the program's objectives. Quantitative research does not only serve an explanatory function; this study also allowed for the evaluation of outcomes in the area of social activation of the elderly, which were not specified in ASOS but came as a result of its implementation. The method based on the analysis of a case study presented in the article allows for an in-depth examination of the outcomes achieved by the implementation of ASOS in the Active Regardless of Age project, in the context of its main objective, i.e., social activation of older people in Poland.

\section{Impact evaluation: the methodological approach}

The Active Regardless of Age project was one among many initiatives supported by ASOS in 2015. The context of the project's implementation is significant for the 
qualitative research of the intervention. The analyzed intervention was implemented in Gdańsk from 1 April 2015 to 31 December 2015 by the non-governmental organization Towarzystwo Edukacyjne Wiedza Powszechna (TEWP); 60 people aged over 60 participated in the initiative (TEWP, 2015: 1-2).

The choice of the project for impact evaluation was intentional. At the stage of selection of a case study for analysis, the following criteria were used:

1. The project was completed.

2. The project achieved its objectives.

3. The project supported beneficiaries aged 60 and above who were excluded or threatened with exclusion and characterized by a low level of social activity.

4. The selected project was implemented by an institution that guaranteed free and unlimited access to all project documentation and permitted to conduct individual interviews and group interviews (focus groups) with the project beneficiaries and their families.

The evaluated project met all of the selection criteria above. It was implemented under the first priority of the 2014-2020 ASOS and intended to improve the social participation of the elderly by giving them access to new knowledge, individual and social skills, and social competencies. Participation in the project was supposed to help seniors achieve and maintain physical, mental, and social well-being. Sixty elderly people at the age of 60 and above were involved in the initiative. They took part in different types of lectures, classes, and workshops devoted to, among other things: a healthy lifestyle, learning a new language, social activities for the local community; they also received various consultations and advisory services in order to improve their physical, mental, and social well-being and their quality of life.

Conducting an in-depth assessment by using the impact evaluation method enabled the authors to investigate the mechanisms, causes, and relations between the inputs and results, as well as the effects of the project implementation (Westhorp, 2014). In order to verify the impact the project had on the elderly, the following hypotheses were formulated:

1. Thanks to the participation in the project, the direct beneficiaries experienced a positive change in their personal and social situation.

2. The positive change occurred gradually and was in line with gaining new knowledge, learning new skills, and developing new social contacts by the direct beneficiaries of the project.

3. The participation of the elderly in the project gave rise to change in their life, which occurred as the intended and unintended outcome of the project.

4. From the beneficiaries' subjective perspective, participation in the project improved their quality of life. 
5. The implementation of the project stimulated greater interest in the problems of the elderly among their families and the local community.

6. The participation of the elderly in the project had a positive influence on their social activation and their better integration with the local community, also in the scope of future activities.

In the impact evaluation of the project, a case-based approach was adopted. Accordingly, the intervention is considered as a complex system of interacting causes that result in concrete outcomes. The impact analysis carried out for the purpose of this article comprised of quantitative data from a previous evaluation, collected by the TEWP, and contextual qualitative methods; the assessed project was an example of a local intervention oriented towards the specific needs of a chosen age group, i.e., the elderly.

The following qualitative methods were implemented in the study:

- Analysis of the project documentation: the application form for funding with the project description, evaluation report made by the TEWP, final project implementation report.

- Semi-structured individual interviews with the senior citizens who were the main and direct project beneficiaries -6 interviews.

- Semi-structured individual interviews with the service deliverers who participated in the project -4 interviews.

- Semi-structured individual interviews with members of the senior citizens' families -2 interviews.

- A semi-structured individual interview with the project coordinator - 1 interview.

- A focus interview with the elderly - the focus group consisted of 5 project beneficiaries.

The assessment did not only concentrate on the intended changes, which were assumed as the project's outcomes, but also referred to unintended changes, both positive and negative. Logically, the program/project creators did not assume negative changes; nevertheless, it was possible that the intervention could bring about negative results for the involved senior citizens.

The analysis of these indicators answered the question of whether the intended changes, especially in the field of the increase in the senior citizens' social participation, were caused by the project implementation.

Furthermore, since this study has a contextual character, it was possible to analyze how different factors determined the change. This was especially important in defining the psychological changes which were produced as a result of the project implementation. Semi-structured interviews with the project stakeholders made it possible to understand the mechanism which brought about the changes. One of the 
aims of implementing the impact evaluation process was to make a list of indicators that contained outcomes achieved as the result of the intervention. The proposed list is limited in comparison with the list of outcomes produced in the project and revealed in the conducted study. This ensuing difference is a consequence of the fact that a part of these outcomes was difficult to measure by the indicators.

\section{Impact evaluation of the Active Regardless of Age project}

The aim of the impact evaluation of the project was to identify changes, if any, in the social situation of the elderly people who were the direct beneficiaries of this intervention, which were caused by the project implemented as part of ASOS. As a result of the conducted study, its main outcomes were identified. The research was carried out in order to examine whether the project achieved its stated objectives. So far, an overall impact evaluation of ASOS has not been undertaken. For organizational and financial reasons, the research team was unable to evaluate the entire ASOS; thus, one project was selected for a qualitative evaluation as part of this case study.

Although the TEWP, being the entity responsible for the project implementation, made an evaluation of the intervention, the findings were limited. Moreover, this evaluation focused on the selected social changes caused by the project and did not consider factors that might have had a positive or negative impact on these changes. The results of the impact evaluation demonstrate that the planned and achieved outcomes of the Active Regardless of Age project primarily centered around the new educational offer and new forms of support for the elderly, which finally brought about social change in their life (Oferta organizacji pozarzadowej..., 2015: 10-11; TEWP, 2016: 1-4). Being the target group of the project, senior citizens experienced various types of changes produced by the intervention. It is worth noting that the intervention resulted not only in intended but also in unintended changes.

The main intended aim of the project was achieved; it was defined as "the social activation of elderly people aged over 60 who are in a difficult situation, sometimes affected by a slight disability or being at risk of exclusion, through a comprehensive educational offer which should enable the project beneficiaries to acquire knowledge and skills necessary to improve their standard of living in a changing world and maintain physical, mental, and intellectual well-being" (Oferta organizacji pozarzadowej..., 2015: 2). Furthermore, the aim of the project was in line with the main objective of ASOS, set as the: "Improvement of the quality and the standard of living of older people for the dignified aging through social activation." The effect 
that the intervention had on reaching the aims of ASOS and the analyzed project was verified through a list of outcomes achieved in the project.

The results of the individual interviews demonstrate that, thanks to the involvement in the project, the elderly started to "go out" into the community and engage in community life more often. By participating in the project, the senior citizens met new people and developed new social contacts and relations. In some cases, new friendships were made. This physical "going out" into the public sphere was the beginning of the wider engagement of the elderly in the local community life. The seniors started to perceive the public sphere not as a place where they are abandoned, but as an opportunity for meeting people who are at the same age, have a similar style of thinking and living, share the same views and face similar everyday life challenges. This change was intended and anticipated as a result of the project. Establishing new social contacts finally created new social ties and supported the elderly in their engagement in voluntary activities. Five interviewed project beneficiaries declared that they were involved in different voluntary activities at the local level, which concerned voluntary work for community day-care centers, assistance for children from families affected by social problems and social threats, engagement in support for other elderly people who live in nursing homes in Gdańsk and participation in organizing local cultural festivals and events. The project coordinator mentioned that a few beneficiaries did voluntary work for the TEWP. One person volunteered in a scientific research project carried out by the researchers from the University of Gdańsk. Engagement of the elderly in voluntary activity was one of the main intended outcomes, designed at the stage of mapping the project. Mobilizing engagement was important for beneficiaries from two perspectives, psychological and social: they felt more adequately integrated with the local community and found a new position in the local public space, as well as changed their attitude towards their role in society. All the project beneficiaries started to feel more self-confident, as useful and essential members of the local community. Two interviewed people reported that the new voluntary duties mobilized them to improve the organization of their personal everyday life.

The second group of outcomes which were achieved in the project refers to new skills learned by the elderly. These outcomes were intended and reached by organizing regular classes and workshops for the beneficiaries. Learning new computer and language skills was considered by the elderly as a chance for improving the way they function in everyday life. They were interested in being able to communicate with their relatives who live abroad via Skype and by using new computer technologies for contacting financial and public institutions or public services providers. These new skills resulted in an additional positive, albeit unintended, change in the 
lives of the beneficiaries, i.e., they started to feel more self-confident and independent from people who helped them with using new technologies. The elderly started to use computers, the Internet, and mobile phones to deal with everyday issues such as paying bills online, ordering cultural and recreational services, and looking for information. They felt that they could rely on themselves more than before the project. Furthermore, learning English language skills was particularly important for three beneficiaries who had families living in the United Kingdom. Thanks to learning English, the seniors were able to communicate directly with their daughters-inlaw (two cases) who were not Polish. Moreover, the three beneficiaries used the new skills during trips abroad.

Participation in psychological workshops and individual meetings with a therapist had a positive impact on the mental well-being of the beneficiaries. This outcome was intended and was achieved through providing psychological support, which helped the elderly cope with difficult life situations: loneliness, disability, health problems of family members, and financial problems. Legal consultations supplemented the psychological assistance and had a positive influence on finding solutions to difficult situations the elderly face. After the psychological and legal workshops, the individual and subjective sense of safety among project beneficiaries increased; they also started to perceive their lives as more stable and predictable.

The next positive outcome which was achieved thanks to the intervention was the improved physical well-being of the beneficiaries experienced by each interviewed elderly person. The beneficiaries participated in kinesigerontotherapy. Training plans were adjusted to the needs, physical condition, and abilities of the elderly people. The coach used different training methods, e.g., Nordic walking and gymnastics, which improved the beneficiaries' physical strength, flexibility, agility, coordination, physical and mental balance. Finally, all the beneficiaries who participated in the semi-structured individual interviews and the focus interview emphasized that they felt much better thanks to doing physical exercises in the company of others. Therefore, it is clear that this training had a positive impact on the senior citizens' subjective sense of physical and mental well-being. Some of them claimed that they reduced the number of painkillers they took and the frequency of appointments with the general practitioner. Furthermore, these physical activities also had an additional social dimension and significance in the process of the senior citizens' social activation. The main motivation for participation in the sports classes was meeting with people from the training group and spending time together with them.

The next unintended change brought about by the project was the transformation of the elderly citizens' style of living. Although the project and all the courses, training, and workshops finished on 31 December 2015, the beneficiaries declared 
that they met each other and their kinesigerontotherapy coach once a week and that they continued to do physical exercise. It means that the change in their style of living is long-term and permanent and that social activation has been observed even after the project is finished. All the beneficiaries reported that before their participation in the project, they spent most of their time at home. They were physically and socially passive and felt excluded from the public sphere and community life. Half a year after the project completion, the elderly remained active and keen on doing physical exercise, meeting other people, and spending time together. This change in the style of living of the senior citizens who participated in the project was unintended but significant from a psychological and social perspective.

Table 2. List and types of outcomes achieved in the Active Regardless of Age project

\begin{tabular}{|c|c|c|c|c|c|c|c|c|}
\hline Outcomes & Int. & Unint. & Pos. & Neg. & Psych. & Social & Prim. & Second. \\
\hline New social contacts of beneficiaries & + & & + & & + & + & & + \\
\hline $\begin{array}{l}\text { Involvement of beneficiaries in voluntary } \\
\text { activities }\end{array}$ & + & & + & & + & + & + & \\
\hline New language skills of beneficiaries & + & & + & & & + & + & \\
\hline New computer skills of beneficiaries & + & & + & & & + & + & \\
\hline $\begin{array}{l}\text { New manual and artistic skills of } \\
\text { beneficiaries }\end{array}$ & + & & + & & & + & + & \\
\hline Increased self-confidence of beneficiaries & & + & + & & + & & & + \\
\hline Better mental well-being of beneficiaries & + & & + & & + & & + & \\
\hline Better physical well-being of beneficiaries & + & & + & & + & & + & \\
\hline Changing the style of living by beneficiaries & & + & + & & & + & & + \\
\hline $\begin{array}{l}\text { New educational services for elderly people } \\
\text { offered by the Towarzystwo Edukacyjne } \\
\text { Wiedza Powszechna }\end{array}$ & + & & + & & & + & + & \\
\hline $\begin{array}{l}\text { Better understanding of the psychological } \\
\text { and social needs of elderly people by } \\
\text { families and local community }\end{array}$ & + & & + & & & + & + & \\
\hline
\end{tabular}

Source: own research based on the data collected from individual semi-structured interviews with project stakeholders.

The change the project brought about in the seniors' lives was also noticed by their relatives. They came to understand that their elders had their own psychological and social needs, and the project opened a chance for meeting them. In one case, the start of the process of accepting this change posed a challenge because it reshaped the relations and division of roles in the family structure. In practice, this meant that one of the senior ladies decided to stop looking after her grandchild and started to engage in the project and voluntary activities. Although these new circumstances created a problem for how the family functioned, finally, the relatives understood 
and acknowledged the new situation. In another case, the second interviewed family member supported his mother's new interest and hobby and the development of her social contacts. Furthermore, the local community-represented by community organizations from Gdańsk-recognized the needs and expectations of the elderly. These organizations became engaged in recruiting the elderly for the project and collected their opinions about what kind of support they needed and expected. The local association of pensioners and disabled people from Gdańsk, local Catholic organizations, and the TEWP participated in the recruitment process and had direct contact with different age groups of seniors from Gdańsk. These social actors, who represented the local civil society in Gdańsk, discovered the main and varied problems of different groups of local elderly people, including those who eventually were not engaged in the project.

$$
* * *
$$

An analysis of the contents of Table 3 shows that both groups of outcomes are completely convergent, and the desired changes in social activation of the elderly provided for in ASOS were achieved in the project.

Table 3. Comparison of outcomes provided by ASOS with the outcomes which were produced in the Active Regardless of Age project

\begin{tabular}{|c|c|c|}
\hline No. & Intended outcomes provided by ASOS & $\begin{array}{l}\text { Intended outcomes produced } \\
\text { in the Active Regardless of Age project }\end{array}$ \\
\hline 1. & $\begin{array}{l}\text { Increase in diversity and improvement of the quality of } \\
\text { educational services for elderly people }\end{array}$ & $\begin{array}{l}\text { New educational services for elderly people offered } \\
\text { by the TEWP }\end{array}$ \\
\hline 2. & $\begin{array}{l}\text { Creation of the conditions for intra- and } \\
\text { intergenerational integration of elderly people by using } \\
\text { the existing social infrastructure }\end{array}$ & $\begin{array}{l}\text { New social contacts of project beneficiaries } \\
\text { and internal integration of seniors with the local } \\
\text { community from Gdańsk }\end{array}$ \\
\hline 3. & $\begin{array}{l}\text { Development of the diversified forms of social } \\
\text { activity containing voluntary services, participation } \\
\text { in decision-making processes and the public sphere, } \\
\text { and the contribution of elderly people to public policy } \\
\text { development }\end{array}$ & $\begin{array}{l}\text { Involvement of beneficiaries in different types of } \\
\text { voluntary activities: cooperation with local civil society } \\
\text { organizations, engagement in local festivals and } \\
\text { events, support for other excluded social groups like } \\
\text { children, dependent elderly people }\end{array}$ \\
\hline 4. & $\begin{array}{l}\text { Increased access to and quality of social services and } \\
\text { support for activities in the area of self-organization } \\
\text { and self-help }\end{array}$ & Involvement of beneficiaries in voluntary activities \\
\hline
\end{tabular}

Source: MPiPS (2014a: 10-11); own research based on the data collected from individual semi-structured interviews with project stakeholders.

Part of the outcomes which were achieved as the result of the project is measurable by quantitative indicators. The list of quantitative indicators is presented in Table 4 . 
Table 4. Quantitative indicators for outcomes achieved in the Active Regardless of Age project

\begin{tabular}{|c|l|c|l|}
\hline No. & \multicolumn{1}{|c|}{ Name of the indicator } & $\begin{array}{c}\text { Value of the } \\
\text { indicator }\end{array}$ & Source of information \\
\hline 1. & $\begin{array}{l}\text { The number of new social relations initiated } \\
\text { by beneficiaries of the project }\end{array}$ & 32 & $\begin{array}{l}\text { - Semi-structured interviews with beneficiaries } \\
\text { of the project }\end{array}$ \\
\hline 2. & $\begin{array}{l}\text { The number of new voluntary activities taken } \\
\text { up by beneficiaries after finishing the project }\end{array}$ & 5 & $\begin{array}{l}\text { - Semi-structured interviews with beneficiaries } \\
\text { of the project } \\
\text { - Semi-structured interview with the project } \\
\text { coordinator }\end{array}$ \\
\hline
\end{tabular}

Source: own research based on the data collected from individual semi-structured interviews with the project stakeholders and project documentation analysis.

Some of the outcomes achieved thanks to the project are immeasurable by quantitative indicators but can be assessed based on the project stakeholders' opinions expressed in the semi-structured individual interviews and the focus interview. The outcomes which cannot be measured by quantitative indicators are connected with psychological changes, applicable to mentality, as well as physical and mental well-being.

It must be considered that the findings from the analysis presented above are based on one case study $(\mathrm{n}=1)$, which means that the possibility of drawing general conclusions based on $n=1$ case study for the entire ASOS is limited. The examined project is representative of ASOS only from the qualitative perspective and serves as an example of a study and an explanation to how the program operates in relation to the outcomes achieved through its implementation. The impact evaluation of the Active Regardless of Age project shows what changes and outcomes can be caused by this kind of intervention (ASOS); nonetheless, it is not an exhaustive list of possible variables of the possible outcomes that can occur.

\section{References}

Błędowski, P. (2017). Opieka długoterminowa w Polsce wobec starzenia się ludności. In: P. Lewandowski, J. Rutkowski (Eds.), Starzenie się ludności, rynek pracy i finanse publiczne $w$ Polsce: 41-44. Warszawa: Przedstawicielstwo Komisji Europejskiej w Polsce. Retrieved from: https://ibs.org.pl/app/uploads/2017/03/Starzenie-si\%c4\%99-ludno\%c5\%9bci-rynek-pracy-i-finanse-publiczne-w-Polsce.pdf (accessed: 6.05.2020).

Boudiny, K. (2013). Active ageing: From empty rhetoric to effective policy tool. Ageing and Society, 33: 1077-1098. DOI: 10.1017/S0144686X1200030X. 
EC (European Commission) (1999). Communication for the Commission: Towards a Europe for all ages. Promoting Prosperity and Intergenerational Solidarity. Brussels: European Commission. Retrieved from: https://ec.europa.eu/employment_social/social_situation/ docs/com221_en.pdf (accessed: 29.12.2020).

European Parliament and European Council (2011). Decision No 940/2011/EU of the European Parliament and of the Council of 14 September 2011 on the European Year for Active Ageing and Solidarity between Generations. Retrieved from: http://publications.europa.eu/en/ publication-detail/-/publication/08a91b5c-c527-4cdc-822a-6a7d0a691dd2/language-en (accessed: 16.04.2020).

Gertler, P., Martinez, S., Premand, P., Rawlings, L., Vermeersch, C. (2011). Impact Evaluation in Practice. Washington, DC: World Bank.

GUS (Główny Urząd Statystyczny) (2009). Prognoza ludności na lata 2008-2035. Warszawa: Główny Urząd Statystyczny.

GUS (Główny Urząd Statystyczny) (2016). Ludność w wieku 60+. Struktura demograficzna i zdrowie. Retrieved from: http://stat.gov.pl/obszary-tematyczne/ludnosc/ludnosc/ludnosc-w-wieku-60-struktura-demograficzna-i-zdrowie,24,1.html (accessed: 14.04.2020).

Kiełczewska, A., Lewandowski, P. (2017). Starzenie się ludności a podaż pracy w Polsce w horyzoncie roku 2050. In: P. Lewandowski, J. Rutkowski (Eds.). Starzenie się ludności, rynek pracy i finanse publiczne w Polsce: 11-16. Warszawa: Przedstawicielstwo Komisji Europejskiej w Polsce. Retrieved from: https://ibs.org.pl/app/uploads/2017/03/Starzenie-si\%c4\%99-ludno\%c5\%9bci-rynek-pracy-i-finanse-publiczne-w-Polsce.pdf (accessed: 6.05.2020).

Klimowicz, M., Michalewska-Pawlak, M. (2018). Znaczenie analizy jakościowej w ewaluacji polityk publicznych na przykładzie Programu ASOS. Problemy Polityki Społecznej. Studia i Dyskusje, 40(1): 87-105.

Klimowicz, M., Michalewska-Pawlak, M. (2019). Ewaluacja inwestycyjnych programów polityki społecznej na przykładzie Rządowego Programu na Rzecz Aktywności Społecznej Osób Starszych. Polityka Społeczna, 5-6: 8-14.

Kubiak, M. (2015). Uwarunkowania aktywności społecznej seniorów na przykładzie realizacji Programu ASOS przez organizację pozarządową. In: M. Leszczyński, M. Kubiak (Eds.), Polityka społeczna dla bezpiecznego rozwoju: 337-353. Gdańsk: Instytut Politologii Uniwersytetu Gdańskiego.

Leszko, M., Zając-Lamparska, L., Trempala, J. (2015). Aging in Poland. The Gerontologist, 55(5): 707-715. DOI: doi.org/10.1093/geront/gnu171.

MPiPS (Ministerstwo Pracy i Polityki Społecznej) (2012). Krajowy Plan Działania na rzecz Europejskiego Roku Aktywności Osób Starszych i Solidarności Międzypokoleniowej 2012 w Polsce, Warszawa. Retrieved from: http://analizy.mpips.gov.pl/images/stories/publ_i_ raporty/ER2012/PL_KPD\%20ER\%202012.pdf (accessed: 10.03.2020).

MPiPS (Ministerstwo Pracy i Polityki Społecznej) (2014a). Rządowy Program na rzecz Aktywności Społecznej Osób Starszych na lata 2014-2020, Warszawa. Retrieved from: https:// www.mpips.gov.pl/gfx/mpips/userfiles/_public/1_NOWA\%20STRONA/Seniorzy/Program\%20ASOS\%202014-2020.pdf (accessed: 14.03.2020). 
MPiPS (Ministerstwo Pracy i Polityki Społecznej) (2014b). Sprawozdanie z realizacji Rządowego Programu na rzecz Aktywności Społecznej Osób Starszych na lata 2012-2013 - rok 2013, Warszawa. Retrieved from: https://das.mpips.gov.pl/source/Sprawozdanie\%20z\%20 realizacji\%20Rzdowego\%20Programu\%20na\%20rzecz\%20Aktywnoci\%20Spoecznej \%20Osb\%20Starszych\%20na\%20lata\%202012-2013-rok\%202013.pdf (accessed: 16.05.2020).

MPiPS (Ministerstwo Pracy i Polityki Społecznej) (2015). Sprawozdanie z realizacji Rządowego Programu na rzecz Aktywności Społecznej Osób Starszych na lata 2014-2020 - rok 2014, Warszawa. Retrieved from: https://das.mpips.gov.pl/source/Sprawozdanie\%20z\%20 realizacji\%20Rzdowego\%20Programu\%20na\%20rzecz\%20Aktywnoci\%20Spoecznej\% 20Osb\%20Starszych\%20na\%20lata\%202012-2013-rok\%202013.pdf (accessed: 16.05.2020).

MRPiPS (Ministerstwo Rodziny, Pracy i Polityki Społecznej) (2016). Sprawozdanie z realizacji Rządowego Programu na rzecz Aktywności Społecznej Osób Starszych na lata 2014-2020 - rok 2015, Warszawa. Retrieved from: https://das.mpips.gov.pl/source/Sprawozdanie $\% 20$ z\%20realizacji\%20Rzdowego\%20Programu\%20na\%20rzecz\%20Aktywnoci\%20Spoecznej\%20Osb\%20Starszych\%20na\%20lata\%202014-2020\%20za\%20rok\%202015.\%5b1\%5d. pdf (accessed: 20.05.2020).

MRPiPS (Ministerstwo Rodziny, Pracy i Polityki Społecznej) (2017). Sprawozdanie z realizacji Rządowego Programu na rzecz Aktywności Społecznej Osób Starszych na lata 2014-2020 - rok 2016, Warszawa. Retrieved from: https://das.mpips.gov.pl/source/ASOS\%202016\%20 wyniki/Sprawozdanie\%20ASOS\%202016.pdf (accessed: 22.05.2020).

MRPiPS (Ministerstwo Rodziny, Pracy i Polityki Społecznej) (2018). Sprawozdanie z realizacji Rządowego Programu na rzecz Aktywności Społecznej Osób Starszych na lata 2014-2020 - rok 2017, Warszawa. Retrieved from: https://das.mpips.gov.pl/source/Sprawozdanie $\% 20$ ASOS\%202017.pdf (accessed: 22.05.2020)

MRPiPS (Ministerstwo Rodziny, Pracy i Polityki Społecznej) (2019). Sprawozdanie z realizacji Rządowego Programu na rzecz Aktywności Społecznej Osób Starszych na lata 2014-2020 - rok 2018, Warszawa. Retrieved from: https://das.mpips.gov.pl/source/2019/Sprawozdanie\%20ASOS\%202018_06_09_2019.pdf (accessed: 22.05.2020).

NIK (Najwyższa Izba Kontroli) (2019). Realizacja rządowych programów na rzecz aktywności społecznej osób starszych. Informacja o wynikach kontroli. Retrieved from: https://www. nik.gov.pl/plik/id,21376,vp,24016.pdf (accessed: 10.05.20).

Oferta organizacji pozarządowej/podmiotu, o którym mowa w Art. 3 Ust. 3 ustawy z dnia 24 kwietnia 2003 r. o działalności pożytku publicznego i o wolontariacie (dz. U. Z 2014 r. Poz. 1118, 1138 i 1146). Realizacji zadania publicznego składana w 2015 roku na podstawie Rządowego programu na rzecz aktywności społecznej osób starszych na lata 2014-2020(2015). Oferta numer: 7114.

Rokicki, A. (2016). Starość nie znaczy bierność - współczesne metody aktywizowania seniorów. Annales Universitatis Mariae Curie Skłodowska Lublin-Polonia, Sectio J. XXIV (1): 185-198. DOI: 10.17951/j.2016.29.1.185.

TEWP (Towarzystwo Edukacyjne Wiedza Powszechna) (2015). Raport ewaluacyjny projektu „Aktywni bez względu na wiek II”. Gdańsk: TEWP.

TEWP (Towarzystwo Edukacyjne Wiedza Powszechna) (2016). Sprawozdanie końcowe z wykonania zadania publicznego „Aktywni bez względu na wiek”. Gdańsk: TEWP. 
Walker, A. (2013). The emergence and application of active ageing in Europe. Journal of Aging and Social Policy, 21: 75-93. DOI: 10.1080/08959420802529986.

Westhorp, G. (2014). Realist Impact Evaluation. An Introduction. London: Overseas Development Institute.

WHO (World Health Organization) (2002). Active ageing: A policy framework. Geneva: WHO. Retrieved from: https://apps.who.int/iris/bitstream/handle/10665/67215/WHO_NMH_ NPH_02.8.pdf;jsessionid=8C2BB6064A1BA1E0B1BB3B38DCC48A26? sequence $=1$ (accessed: 28.12 .2020$)$.

Wiktorska-Święcka, A., Klimowicz, M., Michalewska-Pawlak, M., Moroń, D. (2017). Inwestycje społeczne jako nowy paradygmat polityk publicznych $w$ Unii Europejskiej. Warszawa: Wydawnictwo Naukowe Scholar. DOI: 10.7366/9788373839298. 